\title{
Strategi Akomodasi Komunikasi Mahasiswa Asing dalam Interaksi Antarbudaya (Studi pada Mahasiswa Thailand Selatan di UHAMKA)
}

\author{
Farida Hariyati ${ }^{1}$ \\ ${ }^{1}$ Prodi Ilmu Komunikasi, FISIP UHAMKA, Jl. Limau II, Kebayoran Baru, Jakarta Selatan, Indonesia, 12130 \\ *Email Korespondensi: farida@uhamka.ac.id
}

Kata kunci: Akomodasi Divergensi Komunikasi Konvergensi Verbal

Keyword: Accomodation Convergence Divergence Verbal Communication

\section{A B S T R A K}

Studi ini bertujuan untuk menentukan strategi akomodasi komunikasi yang dilakukan oleh Siswa Thailand Selatan karena hambatan yang dialami dalam menjalani interaksi sosial di lingkungan baru membuat komunikasi mereka tidak efektif. Hambatan yang muncul terkait dengan masalah identitas budaya, terutama bahasa. Penelitian ini menggunakan metode kualitatif yang berupaya menjelaskan fenomena secara mendalam melalui pengumpulan data. Informan yang terlibat dalam penelitian ini adalah siswa Thailand Selatan yang belajar di UHAMKA. Hasil penelitian menunjukkan bahwa informan melakukan strategi konvergensi dan divergensi dalam berkomunikasi dengan lingkungan baik dengan sesama mahasiswa dari Indonesia, dosen, dan masyarakat tempat mereka tinggal dengan menggunakan bahasa Indonesia. Mereka mencoba menyesuaikan cara pengucapan kata, volume, dan kecepatan bicara sehingga mereka merasa nyaman dan membuat lebih mudah untuk memahami subjek menggunakan bahasa Indonesia. Ketika komunikasi verbal dianggap tidak berhasil, mereka juga menggunakan komunikasi non-verbal dengan gerakan untuk mengisyaratkan sesuatu untuk menarik perhatian orang lain untuk berkomunikasi.

\section{A B S T R A C T}

This study aims to determine communication accommodation strategies conducted by Southern Thai Students because the obstacles experienced in undergoing social interaction in a new environment make their communication ineffective. The obstacles that arise are related to the issue of cultural identity, especially language. This study uses a qualitative method that seeks to explain the phenomenon in depth through collecting data. The informants involved in this research were Southern Thai students studying at UHAMKA. The results showed that the informants carried out a convergence and divergence strategy in communicating with the environment both with fellow students from Indonesia, lecturers, and the community they live in by using Indonesian. They try to adjust the way of words pronunciation, volume, and speed of speech so that they feel comfortable and made easier to understand subjects using Indonesian. When verbal communication is considered unsuccessful, they also use non-verbal communication with gestures to signal something to attract the attention of others to communicate.

\section{PENDAHULUAN}

Dinamisasi mobilitas mahasiswa (student mobility) dan internasionalisasi pendidikan tinggi telah berubah secara menonjol sejak 1990-an (Sinlarat, 2013). Asia menjadi tempat potensial dalam mobilitas mahasiswa, mobilitas program, dan berbagai bentuk inovatif dalam pengelolaan dan regulasi pendidikan internasional (Hendarman, 2013). Keberadaan mahasiswa asing dari kawasan Asia, ASEAN, termasuk mahasiswa Thailand Selatan di beberapa Perguruan Tinggi di Indonesia, baik negeri, swasta, dan khususnya perguruan tinggi
Muhammadiyah menjadi sebuah fenomena baru dalam penyelenggaraan pendidikan tinggi. Kota Jakarta menjadi salah satu pilihan bagi mahasiswa Thailand Selatan (Pattani) guna melanjutkan studi lanjut ke perguruan tinggi. Pasalnya, Indonesia khususnya DKI Jakarta dianggap menjadi negara yang lebih akomodatif yang mayoritas Islam.

Setiap manusia senantiasa berupaya untuk memahami dan memberikan makna terhadap apa yang terjadi dalam dirinya ataupun terhadap lingkungannya. Demikian pula dengan para mahasiswa Thailand Selatan yang ada di dan memiliki kedekatan kultural, juga agama 
Universitas Muhammadiyah Prof. Dr. HAMKA (UHAMKA). Pada masa awal tinggal dan berinteraksi dengan masyarakat lokal, mahasiswa Thailand Selatan mengalami keterkejutan budaya (culture shock) dan menemui kesulitan dalam menyesuaikan dengan lingkungan baru, baik dari aspek bahasa, kebiasaan, pergaulan, makanan, maupun pola komunikasi yang sangat berbeda dengan di negara asal mereka. Termasuk ketika mereka mengikuti perkuliahan dalam Bahasa Indonesia sebagai bahasa pengantar. Meskipun para mahasiswa Thailand Selatan telah mendapatkan pelatihan Bahasa Indonesia sebelum memasuki perkuliahan, namun hal ini belum mencukupi sebagai modal untuk berinteraksi dengan sesama mahasiswa Indonesia dan masyarakat di lingkungan tempat tinggal mereka. Ketika mereka menemui kesulitan untuk mengungkapkan sesuatu dalam bahasa verbal atau sebaliknya, lawan bicara tidak memahami maksud mereka, maka yang mereka lakukan adalah menggunakan isyarat, dengan menunjuk hal yang dimaksudkan (nonverbal).

Beberapa hambatan komunikasi tersebut tentu mempengaruhi efektivitas komunikasi mereka saat berinteraksi. Komunikasi yang begitu penting dalam setiap aspek kehidupan manusia, berubah menjadi kompleks manakala para pelakunya berbeda budaya.

Jika kita mengamati suatu interaksi dengan cermat, misalnya dua orang yang sedang berbicara, kita terkadang menyadari bahwa salah seorang dari mereka mencoba menyesuaikan perilakunya dengan perilaku lawan bicaranya (Morissan, 2014). Ketika terjadi pembicaraan, orang biasanya akan saling menunjukkan mimik dan perilakunya. Bahkan seringkali meskipun kita bicara pada orang dengan bahasa dan gesture yang sama, kita akan bicara dengan nada dan gaya yang sama. Howard Giles (dalam West \& Turner, 2007) menjelaskan tentang motivasi dan konsekuensi terhadap apa yang akan terjadi ketika terjadi percakapan dua orang merubah gaya komunikasi mereka. Selama komunikasi berlangsung, orang akan mencoba untuk mengakomodasi atau menyesuaikan gaya bicara mereka terhadap orang lain. Hal ini dilakukan dalam dua cara yaitu Konvergen dan Divergen. Kelompok-kelompok yang memiliki kebanggaan budaya yang kuat (strong cultural pride) seringkali cenderung menggunakan divergen untuk menunjukkan identitas kelompok. Konvergen terjadi apabila terdapat kebutuhan yang kuat terhadap kesepakatan sosial, terutama dari indovidu yang posisinya tidak kuat (dalam identitas budaya).

\section{Literature Review}

Riswi dan Mulyana (2015) mengkaji komunikasi antarbudaya dalam bingkai ekspresi komunikasi yang merupakan ungkapan, perasaan, ataupun perilaku yang ditunjukkan pada saat melakukan aktivitas komunikasi, dilakukan baik secara verbal maupun nonverbal. Dalam penelitian ini ditemukan bahwa beberapa mahasiswa Patani Thailand di kampus UNISBA Bandung yang melakukan penyesuaian diri setelah mengalami keterkejutan budaya (culture shock) dan mengalami kesulitan dalam berinteraksi sosial dengan mahasiswa dari Indonesia. Cara untuk mengatasi halangan-halangan yang dialami adalah melakukan ekspresi komunikasi baik secara verbal maupun non-verbal. Cara verbal misalnya mengucapkan 'assalaamu'alaikum' setiap bertemu dengan teman-temannya, disertai dengan komunikasi non-verbal yaitu sikap tubuh yang tenang, tidak reaktif, sabar, dan mampu memperhatikan lawan bicara.

Aryapradana (2012) memaparkan tentang akomodasi para pemain Indonesia yang berinteraksi melalui kompetisi Game Online Battle of Immortals yang terhalang oleh stereotip-stereotip diantara para pemain dari berbagai negara. Stereotip negatif terhadap pemain Indonesa adalah 'miskin', 'cheater', dan 'perusak harga barang'; sementara stereotip positif terhadap pemain Indonesia adalah 'baik', 'ramah', dan 'fairplay'. Game Online membuka peluang bagi para pemain dari berbagai negara untuk berinteraksi melalui dunia virtual, sehingga komunikasi antarbudaya tidak bisa dihindari dan dilakukan secara real time. Akomodasi yang mereka lakukan adalah dengan strategi Konvergensi, Divergensi, dan Over Akomodasi (Akomodasi Berlebihan). Dalam penelitian ini dipaparkan bahwa identitas pemain, baik personal identitiy, relational identity, communal identity, national identity, cyber and fantasy identity, dan organizational identity menjadi penting dalam menentukan interaksi dan hubungan antarpemain. Identitas tersebut pada akhirnya melahirkan stereotip antarpemain yang menentukan strategi akomodasi komunikasi 
yang diterapkan oleh para pemain meskipun tidak bertatap muka.

Menurut Miller (2002), komunikasi merupakan proses, sehingga konseptualisasi komunikasi harus berorientasi proses, sehingga David Berlo (dalam Miller, 2002) mengatakan bahwa 'jika kita menerima konsep tentang proses, maka kita memandang peristiwa dan relasi sebagai sesuatu yang dinamis, terus berlangsung, sering berubah, dan berlanjut. Ketika kita memberi label sesuatu sebagai sebuah proses, artinya kita tidak sedang mengartikan bahwa sesuatu memiliki awal, memiliki akhir, tata urutan yang pasti, dan selanjutnya komunikasi bukanlah sesuatu yang statis, namun terus bergerak. Hal yang menjadi unsur dalam sebuah interaksi proses adalah segala sesuatu saling mempengaruhi'.

Komunikasi dapat dilakukan oleh orangorang yang berbeda latar budayanya sehingga komunikasi antarbudaya diartikan sebagai komunikasi antarpribadi yang dilakukan oleh mereka yang berbeda latar belakang kebudayaan. Menurut Samovar, et al (2010); sejak awal peradaban ketika manusia pertama membentuk kelompok suku, hubungan antarbudaya terjadi setiap kali orang-orang dari suku yang satu bertemu dengan anggota dari suku yang lain dan mendapati bahwa mereka berbeda. Definisi lain mengatakan bahwa yang menandai komunikasi antarbudaya adalah bahwa sumber dan penerimanya berasal dari budaya yang berbeda. Fred E. Jandt mengartikan komunikasi antarbudaya sebagai interaksi tatap muka di antara orang-orang yang berbeda budayanya (intercultural communication generally refers to face-to-face interaction among people of different culture). Sedangkan Collier dan Thomas, mendefinisikan komunikasi antarbudaya "as communication between persons who identify themselves as distinct from 'other in cultural sense (Purwasito, 2003).

Menurut Liliweri (2003), proses komunikasi antarbudaya merupakan interaksi antarpribadi dan komunikasi antarpribadi yang dilakukan oleh beberapa orang yang memiliki latar belakang kebudayaan yang berbeda. Jadi dapat dikatakan bahwa komunikasi antarbudaya terjadi bila produsen atau sumber pesan adalah anggota suatu budaya dan penerima pesannya adalah anggota suatu budaya lainnya.

Akomodasi

didefinisikan sebagai
(Accomodation)

kemampuan untuk menyesuaikan, memodifikasi, atau mengatur perilaku seseorang dalam responnya terhadap orang lain. Dalam sebuah proses komunikasi dan interaksi dalam level interpersonal, terkadang terdapat perbedaan berdasarkan kelompok atau budaya, seperti perbedaan yang muncul pada kelompok usia, dalam aksen, dan etnis, atau dalam kecepatan bicara (West \& Turner, 2007).

Kajian Akomodasi dipengaruhi oleh jumlah individu yang terlibat, situasional dan keadaan budaya, maka dapat diidentifikasi beberapa asumsi (West \& Turner, 2007) : 1) Kemiripan ataupun kesamaan maupun perbedaan tentang pembicaraan dan perilaku akan muncul dalam setiap percakapan; 2) Perilaku atau tata cara yang kita lihat dalam melihat pembicaraan dan perilaku orang lain akan menentukan bagaimana kita mengevaluasi sebuah percakapan; 3) Bahasa dan perilaku memperlihatkan informasi tentang status sosial dan kecenderungan kelompok; dan 4) Akomodasi akan bervariasi dalam tingkatan dan kesesuaiannya, dan norma akan memandu berlangsungnya proses akomodasi

Giles dan para koleganya telah menetapkan sebuah pengamatan umum bahwa para pelaku komunikasi seringkali saling meniru perilaku. Mereka menyebutnya pemusatan (convergence), atau penyamaan. Sebaliknya, pelebaran atau pemisahan (divergence) - atau pemisahan terjadi ketika pembicara mulai melebih-lebihkan perbedaan mereka. Penyesuaian dalam kedua bentuk ini telah dilihat dalam hampir semua perilaku komunikasi, termasuk aksen, kecepatan, kerasnya suara, kosakata, tata bahasa, suara, gerak tubuh, dan fitu-fitur lainnya (Littlejohn, 2009).

1. Konvergensi /Pemusatan (Convergence) Proses awal atau pertama terkait dengan teori akomodasi komunikasi adalah Konvergensi (Convergence). Giles, et al (dalam West \& Turner, 2007) menjelaskan definisi Konvergensi sebagai "sebuah strategi dimana para individu saling beradaptasi dalam perilaku komunikasinya". Orang akan beradaptasi terhadap kecepatan berbicara, jeda, senyuman, tatapan mata, dan perilaku verbal serta nonverbal lainnya. Ketika seseorang melakukan konvergensi, mereka mendasarkan pada persepsi mereka mengenai tuturan atau perilaku orang lain. Terkait dengan persepsi komunikasi orang 
lain, konvergensi juga didasarkan atas atraksi (ketertarikan). Ketika para komunikator saling tertarik, maka mereka akan melakukan konvergensi dalam percakapannya.

2. Divergensi/Pelebaran (Divergence)

Dalam konteks akomodasi, Giles meyakini bahwa para penutur kadang-kadang menonjolkan perbedaan baik secara verbal maupun nonverbal diantara mereka. Strategi inilah yang kemudian disebut dengan divergensi. Berbeda dengan konvergensi, di dalam divergensi tidak terdapat usaha untuk menunjukkan persamaan antara para komunikator. Divergensi merupakan suatu cara bagi para anggota komunitas budaya yang berbeda untuk mempertahankan identitas sosial. Para pelaku komunikasi melakukan divergensi berkaitan dengan kekuasaan atau perbedaan peranan dalam percakapan. Diveregensi sering terjadi dalam percakapan dimana terdapat perbedaan peranan yang cukup tajam (misalnya orang tua - anak; dokter - pasien; atasan - bawahan).

3. Akomodasi Berlebihan (Overaccomodation) Menurut Jane Zuengler (dalam West \& Turner, 2007); akomodasi berlebihan merupakan label yang diberikan kepada penutur yang dianggap terlalu berlebihan. Istilah ini diberikan kepada orang yang walaupun bertindak berdasarkan niat yang baik, justru dianggap merendahkan. Akomodasi berlebihan dapat terjadi alam 3 bentuk: pertama, akomodasi berlebihan sensoris (sensory overaccomodation). Bentuk pertama ini terjadi ketika seorang penutur secara berlebihan ingin mengadaptasi pada lawan bicara yang dianggap memiliki keterbatasan dalam hal tertentu. Keterbatasan disini mengacu pada keterbatasan bahasa dan fisik. Kedua, akomodasi berlebihan ketergantungan (dependency overaccomodation) yang terjadi ketika seorang penutur secara sadar ataupun tidak, menempatkan lawan bicara pada peran yang lebih rendah, sehingga lawan bicara terlihat seperti tergantung pada si penutur. Dalam akomodasi berlebihan jenis ini, lawan bicara juga meyakini bahwa penutur memiliki kontrol atas percakapan sehingga menunjukkan status atau peran yang lebih tinggi. Ketiga, akomodasi berlebihan antarkelompok (intergroup overaccomodation). Tipe ketiga ini melibatkan penutur dan lawan bicara yang berlebihan sehingga gagal untuk mendekati setiap orang sebagai individu. Inti dari akomodasi berlebihan adalah munculnya stereotype, dan pada akhirnya akan membuat jarak yang semakin jauh diantara para pelaku komunikasi.

Zuengler (dalam West \& Turner, 2007) mengatakan bahwa akomodasi berlebihan akan menyebabkan pendengar (lawan bicara) memberikan persepsi bahwa diri mereka tidak setara. Ada beberapa implikasi yang cukup serius dari akomodasi berlebihan, yaitu kehilangan motivasi untuk memahami bahasa lawan bicara secara mendalam, menghindari percakapan, dan membentuk sikap negatif terhadap penutur dan masyarakat. Jika salah satu tujuan komunikasi adalah mencapai makna yang diinginkan (intended meaning), maka akomodasi berlebihan menjadi penghalang yang cukup signifikan bagi tujuan tersebut.

\section{METODE PENELITIAN}

Penelitian ini adalah deskriptif dengan pendekatan kualitatif. Metode yang digunakan dalam penelitian ini adalah studi kasus untuk menelaah dan mengkaji sejumlah variable dalam suatu kasus. Informan dalam penelitian terdiri dari 5 (lima) orang mahasiswa Thailand Selatan yang sedang menjalankan studi jenjang S1 pada beberapa program studi di UHAMKA. Pemilihan subjek atau informan menggunakan teknik purposive sampling. Pengumpulan data yang dilakukan dengan beberapa Teknik yakni : wawancara, observasi, dan dokumentasi, serta untuk memperkuat perolehan data dilakukan melelui triangulasi untuk pemeriksaan data penelitian.

\section{HASIL DAN PEMBAHASAN}

Dalam Memorandum of Understanding (MoU) Nomor 87/I.0/A/2014 tanggal 8 November 2014 antara PP Muhammadiyah dengan SBPAC tentang Pemberian Beasiswa (The Arrangement of Scholarships) yang ditandatangani oleh Ketua Umum PP Muhammadiyah Prof. Dr. HM Din Syamsuddin, MA. dan Police Colonel Tawee Sodsong, disepakati bahwa ada 13 (tiga belas) PTM yang bersedia memberikan beasiswa bagi 
mahasiswa Thailand Selatan, dan salah satunya adalah UHAMKA. The Southern Border Provinces Administrative Center (SBPAC) merupakan organisasi yang didirikan oleh pemerintah Thailand yang memiliki tugas salah satunya memfasilitasi calon mahasiswa baru yang berasal dari Thailand Selatan untuk melanjutkan kuliah di Perguruan Tinggi di Indonesia, khususnya Perguruan Tinggi Muhammadiyah. Naskah kerjasama telah ditandatangani sejak tahun 2009 dan diperpanjang tahun 2014.

UHAMKA merupakan salah satu perguruan tinggi swasta di Jakarta dan sekaligus masuk dalam lima besar Perguruan Tinggi Muhammadiyah di Indonesia. UHAMKA memiliki mahasiswa aktif sebanyak 14.832 orang, yang tersebar dalam 34 program studi (S1 dan S2), dengan 8 fakultas dan Sekolah Pascasarjana. Dari sekian banyak mahasiswa UHAMKA, terdapat 43 orang mahasiswa Thailand Selatan yang belajar di UHAMKA pada jenjang Strata satu.

Keberadaan mahasiswa Thailand Selatan di UHAMKA merupakan salah satu implikasi dari program kerjasama yang dilakukan oleh PP Muhammadiyah dengan berbagai pertimbangan diutarakan oleh para mahasiswa Thailand Selatan dalam memilih UHAMKA sebagai kampus pilihan mereka adalah : 1) Kampus UHAMKA berada di Kota Jakarta. Pada saat penentuan pilihan kampus untuk melanjutkan kuliah di Indonesia, Mahasiswa Thailand Selatan hanya fokus pada 'Jakarta', bukan pada 'UHAMKA'. Yang mereka pahami tentang Indonesia adalah Jakarta, sehingga Jakarta merepresentasikan Indonesia. Sebelum mereka kuliah di Indonesia, mereka hanya mengetahui Jakarta dari buku, berita di media, maupun informasi dari orang lain; 2) Akses transportasi yang mudah dari Jakarta ke Thailand dan sebaliknya. Transportasi utama tentu adalah melalui udara (pesawat terbang); 3) Dorongan dari orang tua yang mengarahkan mereka untuk kuliah di Indonesia (Jakarta); dan 4) Fasilitas beasiswa yang diperoleh sehingga lebih meringankan beban biaya orang tua mereka.

\section{Profil Informan}

Dalam proses pengumpulan data, penulis melakukan wawancara dengan 5 (lima) orang informan. Informan terdiri dari mahasiswa aktif berasal dari Thailand Selatan yang sedang menjalani perkuliah di UHAMKA. Penulis menerapkan snowball sampling dimana peneliti meminta satu orang informan yang telah diwawancarai untuk memberikan rekomendasi kepada teman-teman informan yang berasal dari Thailand Selatan yang dianggap dapat membantu memberikan informasi untuuk pengumpulan data. Adapun profil informan adalah sebagai berikut :

\section{Tabel 1. Profil Informan Penelitian}

\begin{tabular}{|c|c|c|c|}
\hline No & $\begin{array}{c}\text { Identitas } \\
\text { Mahasisw } \\
\mathbf{a}\end{array}$ & $\begin{array}{c}\text { Fakultas / } \\
\text { Program } \\
\text { Studi }\end{array}$ & Semester \\
\hline 1 & $\begin{array}{l}\text { Siriluk } \\
\text { Ninrat } \\
\text { (Fon) } \\
\text { Lahir: } \\
\text { Yala, } 27 \\
\text { Desember } \\
1995 \\
\text { Jenis } \\
\text { Kelamin: } \\
\text { Perempua } \\
\text { n }\end{array}$ & $\begin{array}{l}\text { FISIP / Ilmu } \\
\text { Komunikasi }\end{array}$ & 5 \\
\hline 2 & $\begin{array}{l}\text { Hafsoh } \\
\text { Hayeehasa } \\
\text { (Afsoh) } \\
\text { Lahir: } \\
\text { Pattani, } 19 \\
\text { Juni } 1993 \\
\text { Jenis } \\
\text { Kelamin: } \\
\text { Perempua } \\
\text { n }\end{array}$ & $\begin{array}{c}\text { FKIP / } \\
\text { Pendidikan } \\
\text { Bahasa dan } \\
\text { Sastra } \\
\text { Indonesia }\end{array}$ & 9 \\
\hline 3 & $\begin{array}{l}\text { Karmee } \\
\text { Piru }\end{array}$ & $\begin{array}{c}\text { FIKES / } \\
\text { Kesehatan }\end{array}$ & 7 \\
\hline
\end{tabular}




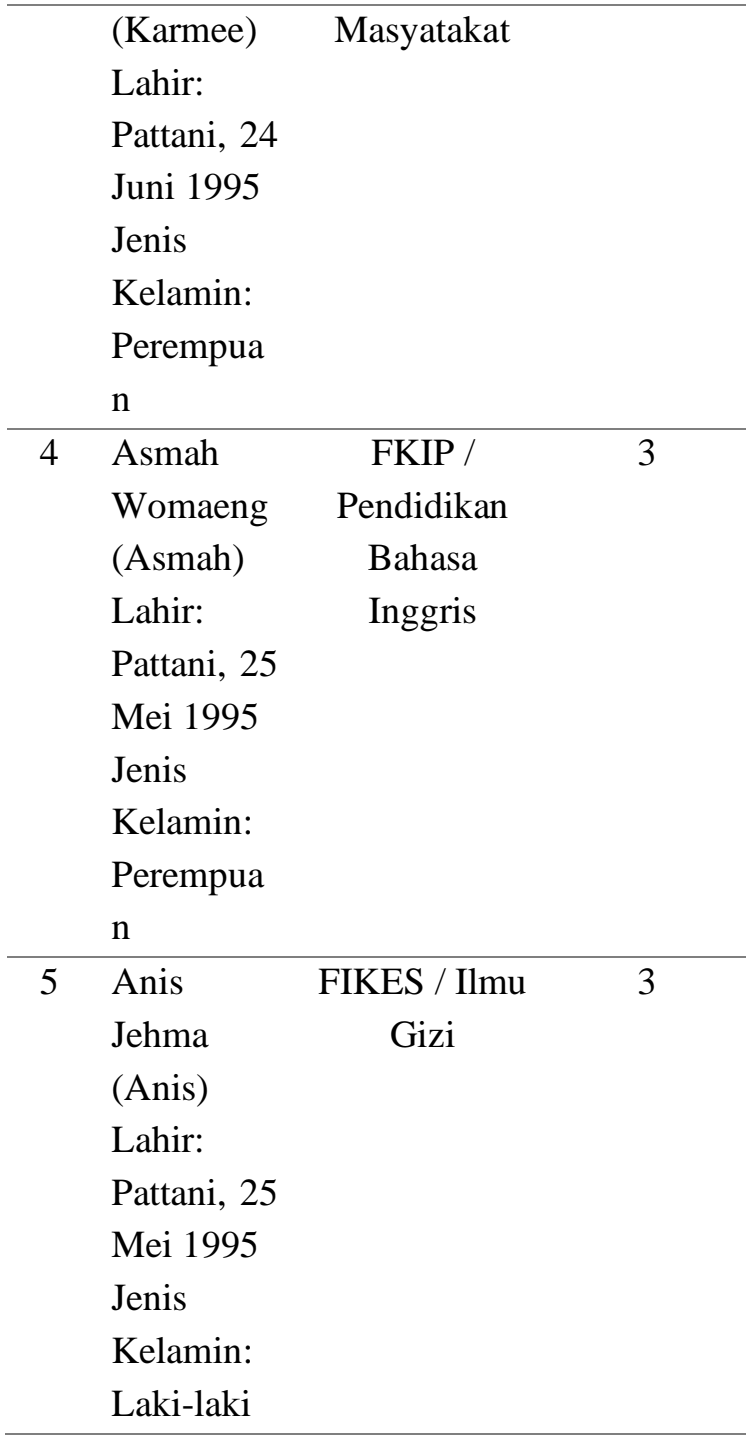

Informan 1 menguraikan pengalaman awal tiba di Jakarta, setelah sempat tinggal di Asrama Mahasiswa UHAMKA (UHAMKA Dormitory) selama satu pekan. Setelah keluar dari UHAMKA Dormitory, Informan 1 sempat tinggal di rumah kontrakan dengan sesama mahasiswa Thailand Selatan selama tiga bulan, namun kemudian memutuskan tinggal di sebuah rumah kos di daerah Kebayoran Baru Jakarta Selatan di mana para penghuninya berasal dari berbagai daerah, namun di tempat tinggal ini Informan 1 memiliki teman kos yang juga berasal dari Thailand Selatan. Secara umum, Informan I terlihat senang berteman dan ramah. Meskipun demikian, berkaitan dengan komunikasi, Informan 1 terlihat pasif dalam menjalani percakapan. Jika tidak mengerti apa yang disampaikan oleh teman-teman, maka temannya mengulang perkataan lebih lambat dan menggunakan kosakata yang lebih familiar, sehingga setelah itu, yang bersangkutan akan merespon merespon dengan tertawa, senyum, atau bahasa non-verbal lainnya.

2 tinggal di sebuah rumah kos di daerah Pasar Rebo. Seperti halnya Informan 1, pada awal di kuliah di UHAMKA, Informan 2 tinggal di Dormitory Mahasiswa UHAMKA (RUSUNAWA) selama 2 semester, dan di semester 3 memutuskan untuk pindah ke rumah kos dengan alasan tidak ingin terikat dengan aturan Dormitory. Ketika pertama kali menginjakkan kaki di Jakarta, Informan 2 merasa terkejut dan merasa kesulitan untuk beradaptasi, terutama dalam berkomunikasi karena faktor bahasa yang tidak dipahami. Bahkan Informan 2 hampir memutuskan untuk tidak melanjutkan kuliah dan pulang kembali ke Thailand. Namun atas dorongan dari para senior mahasiswa Thailand Selatan, maka informan 2 berusaha belajar Bahasa Indonesia dengan mengikuti kursus di Dormitory bersama salah satu dosen Pendidikan Bahasa dan Sastra. Selain itu, kultur dan makanan juga menjadi persoalan penting karena memerlukan upaya yang cukup keras dari informan.

Informan 3 tinggal di Rumah Kos yang sama dengan Informan 1. Pada saat pertama kali mengawali kuliah di UHAMKA, Informan 3 tinggal di Sekretariat TSAI (Thailand Student Assosiation in Indonesia). TSAI adalah Asosiasi Mahasaiswa dan Pelajar Thailand Selatan yang kuliah di Indonesia, khususnya Jakarta. Asosiasi ini didirikan dan dinaungi langsung oleh Kedutaan Besar Thailand untuk Indonesia. Informan 3 berkarakter pendiam dan bersahaja. Pada awal tahun 2016 Informan 3 pernah menjadi tenaga mahasiswa magang pada Kantor Urusan Internasional (KUI) UHAMKA selama 6 (enam) bulan.

Informan 4 resmi menjadi mahasiswa UHAMKA pada tahun akademik 2014/2015, bersama Informan 1. Pada tahun 2014/2015 
Informan 4 kuliah pada prodi Ilmu Komunikasi, namun pada tahun kedua (2015/2016) yang bersangkutan pindah ke prodi Pendidikan Bahasa Inggris. Kepindahan prodi disebabkan karena faktor ketidakpahaman dalam memilih program studi, yakni pada saat wawancara dengan The SBPAC, yang dipahami tentang Ilmu Komunikasi adalah berkaitan dengan 'teknologi informasi dan komunikasi' sehingga ada kesalahan dalam penerjemahan dari Bahasa Indonesia ke Bahasa Thailand sehingga ketika menjalani perkuliahan di prodi Ilmu Komunikasi, Informan 4 merasa berat dalam memahami konteks matakuliah yang didominasi dengan pengantar Bahasa Indonesia, maka Informan 4 memutuskan pindah ke prodi Pendidikan Bahasa Inggris karena lebih memudahkan dalam memahami materi perkuliahan karena bahasa pengantar tidak hanya menggunakan Bahasa Indonesia, namun juga dengan Bahasa Inggris yang lebih bersifat internasional. Informan 4 menguraikan pengalaman-pengalaman ketika pertama kali menginjakkan kaki di Jakarta, diantaranya tentang kemacetan yang luar biasa di Jakarta, banyaknya pengemis dan pengamen di jalanan, makanan, dan tentu saja persoalan perbedaan bahasa. Perjuangan untuk memahami Bahasa Indonesia di awal tahun dilakukan dengan selalu membawa kamus Indonesia-Thailand untuk bercakap-cakap dengan lawan bicara dari Indonesia.

Informan 5 merupakan pribadi yang tenang, dan merupakan informan yang paling lancar dalam berkomunikasi dengan Bahasa Indonesia dibandingkan dengan keempat informan lainnya. Informan 5 tinggal di Sekretariat TSAI. Informan 5 mengungkapkan tentang pilihan kuliah di Jakarta karena mendengar cerita dari orang lain dan membaca informasi tentang Jakarta dan membayangkan Jakarta seperti halnya Bangkok. Namun setibanya di Jakarta, persepsi sedikit berubah ketika melihat banyaknya sampah yang tidak dibuang pada tempatnya. Satu hal positif yang membuat Informan 5 bertahan di Jakarta adalah terbentuknya persepsi bahwa orang Indonesia orang baik dan mayoritas muslim, di samping kultur yang mirip dengan Thailand. Dalam mempelajari Bahasa Indonesia, Informan 5 lebih menekankan pada belajar langsung bercakap-cakap dengan teman-teman kuliah. Informan 5 menceritakan pengalaman dalam memilih UHAMKA sebagai tempat kuliah karena tertarik dengan Gizi dan nama tokoh besar Buya HAMKA. Informan 5 adalah seorang pribadi yang cepat beradaptasi, bahkan ikut aktif dalam kegiatan Ikatan Mahasiswa Muhammadiyah (IMM).

\section{Pemahaman Komunikasi Antarbudaya Mahasiswa Thailand Selatan}

Liliweri (2007) mengatakan bahwa komunikasi antarbudaya mengharuskan setiap pelakunya berusaha mendapatkan, mempertahankan, dan mengembangkan aspekaspek kognitif bersama. Seseorang harus mengetahui keberadaan budaya yang menjadi latar belakang kehidupannya, seseorang itu pun harus berusaha untuk mendapatkan dan memahami latar belakang budaya orang lain. Pengetahuan itu diperoleh dari informasi latar belakang kebudayaan orang lain, pengalaman pergaulan yang terus menerus sehingga pengalaman itu dapat mempengaruhi persepsi sikap seseorang terhadap orang lain. Semakin berbeda dua budaya, semakin besar perbedaan antara dua kelompok, dan semakin sedikit kemungkinan untuk saling memahami.

Para informan secara jujur mengakui bahwa pada saat mereka pertama kali berada di Indonesia (Jakarta), mereka merasakan adanya keterasingan yang luar biasa, bahkan beberapa informan mengatakan bahwa mereka sangat terkejut dengan kondisi lingkungan dan perbedaan budaya dengan negara asal mereka. Tahun pertama adalah tahun paling sulit mereka karena perlu upaya keras untuk beradaptasi dengan budaya Indonesia, bahkan dua informan merasa tidak sanggup untuk melanjutkan studi 
dan berniat pulang kembali ke Thailand. Namun keinginan untuk kembali sebelum studi selesai dan rasa keterasingan dari lingkungan budaya baru ini berhasil disingkirkan secara perlahan.

Sarbaugh (dalam Tubbs \& Moss, 2005) mengungkapkan bahwa ada 3 (tiga) prinsip yang berlaku dalam komunikasi antarbudaya, yaitu:

1. Suatu sistem sandi bersama yang tentu saja terdiri dari dua aspek yaitu verbal dan nonverbal. Dalam prinsip pertama ini tentu saja aspek perbedaan bahasa dalam komunikasi verbal menjadi persoalan penting dalam komunikasi antarbudaya mahasiswa Thailand Selatan karena mereka dituntut untuk dapat berbicara dalam Bahasa Indonesia. Aspek nonverbal terlihat ketika mereka tidak mengetahui arti dari pengucapan lawan bicara dari Indonesia.

2. Kepercayaan dan perilaku yang berlainan diantara pihak-pihak yang berkomunikasi merupakan landasan bagi asumsi-asumsi berbeda untuk memberikan respon. Kepercayaan dan perilaku ini dapat mempengaruhi persepsi terhadap apa yang dilakukan oleh orang lain. Para informan mengatakan bahwa mereka tidak memiliki keberanian untuk bertanya pada dosen dalam kegiatan belajar mengajar di kelas. Mereka mengatakan bahwa mereka segan, malu, dan sekaligus takut kepada sebagian besar dosen yang mengajar. Mereka lebih merasa nyaman dengan bertanya kepada teman sekelas untuk menjelaskan materi perkuliahan. Namun demikian tetap ada dosen yang menurut pandangan mereka bersikap ramah dan bisa memahami keterbatasan meraka. Persepsi yang tidak sama terhadap para dosen ini pada akhirnya berimplikasi pada hasil belajar mereka, terutama dalam mata kuliah yang dosennya mereka anggap tidak kooperatif.

3. Tingkat mengetahui dan menerima kepercayaan dan perilaku orang lain.
Artinya bahwa tidak sekedar pengetahuan mengenai perbedaan yang menimbulkan masalah, melainkan juga tingkat penerimaan individu. Keterbatasan pengetahuan para informan tentang budaya Indonesia menjadikan mereka merasa harus bersikap lebih hati-hati dalam menjalankan interaksi sosial. Setelah mengalami satu tahun untuk beradaptasi, para informan mulai dapat mempercayai teman-teman Indonesia untuk membangun relasi lebih dekat. Kedekatan ini pun bersifat selektif, artinya para informan benar-benar memilih teman mana yang dapat memberikan pemenuhan kebutuhan pribadi seperti penerimaan, kontrol, dan afeksi dalam interaksi mereka.

Dalam setiap aktivitas komunikasi memungkinkan untuk munculnya hambatanhambatan (barriers). Hambatan yang nampak pada para mahasiswa Thailand Selatan dalam melakukan komunikasi antarbudaya di Indonesia adalah lebih pada sikap etnosentrisme; dimana etnosentrisme merupakan kecenderungan menghakimi nilai, adat istiadat, perilaku, atau aspek-aspek budaya lain "menggunakan kelompok kita sendiri dan adat istiadat kita sendiri sebagai standar bagi semua penilaian" (Tubbs \& Moss, 2005:254). Etnosentrisme ini yang membuat mahasiswa Thailand merasa pada tahun pertama tidak dapat menerima perbedaan budaya yang mereka temui di Jakarta. Ketika proses rekrutmen mahasiswa baru oleh SBPAC, mahasiswa Thailand ini tidak memperoleh informasi yang lengkap tentang UHAMKA dan Jakarta. Mereka mengetahui Jakarta dan Indonesia hanya sebatas dari orang lain, berita-berita media, buku, maupun internet. Pada semester pertama para informan mengungkan bahwa mereka masih menutup diri dari pergaulan dengan mahasiswa Indonesia, sehingga mereka masih tinggal berkelompok dengan teman dari Thailand, dan setelah tinggal selama sebulan di UHAMKA Dormitory, mereka memutuskan keluar dan tinggal di Sekretariat TSAI. Pada 
tahun kedua, para mahasiswa Thailand Selatan mulai dapat beradaptasi dan membuka diri terhadap teman-teman mahasiswa Indonesia, dan mereka memutuskan meninggalkan Sekretariat TSAI untuk tinggal di tempat kos yang dekat dengan kampus tempat mereka kuliah, dan tinggal terpisah dari teman-teman Thailand yang lain.

\section{Akomodasi Komunikasi Mahasiswa Thailand Selatan di UHAMKA}

Pada hakekatnya, manusia telah berkomunikasi selama ribuan tahun, dan sebagian waktu manusia digunakan untuk berkomunikasi. Meskipun demikian, ketika manusia dilahirkan ia tidak dengan sendirinya dibekali dengan kemampuan untuk berkomunikasi efektif (Tubbs \& Moss, 2008). Kemampuan untuk berkomunikasi efektif bukanlah sesuatu yang bersifat bawaan namun perlu adanya upaya untuk mempelajari dan mengembangkannya. Budaya mampu mengajarkan kepada manusia bagaimana membangun hubungan dengan manusia lain sehingga dapat mengembangkan potensipotensi yang dimiliki.

Budaya dan bahasa memiliki hubungan kausalitas yang tidak dapat dilepaskan dari komunikasi itu sendiri. Hipotesis Saphir-Whorf (Tubbs \& Moss, 2008) menyatakan bahwa dunia ini dipersepsi secara berbeda oleh para anggota komunitas linguistik yang berlainan dan persepsi ini ditransimisikan serta dipertahankan oleh bahasa. Ketika terdapat dua kelompok budaya yang berinteraksi dalam dimensi waktu yang sama, maka yang kemudian terjadi adalah munculnya pilihanpilihan terkait sistem komunikasi apa yang akan digunakan dan seberapa besar tingkat akomodasinya (Giles \& Noel, 2016). Dalam menjalani kehidupan perkuliahan dan pergaulan dengan lingkungan sekitar, para informan memaparkan bahwa terkadang mereka merasa merasa sangat nyaman karena teman-teman memahami keterbatasan dalam penguasaan
Bahasa Indonesia. Namun dalam situasi tertentu, mereka kadang-kadang merasa orang lain, dalam hal ini teman-teman dari Indonesia dan para dosen menyampaikan kalimat atau perkataan yang tidak mereka pahami, namun mahaiswwa Thailand Selatan ini merasa enggan untuk menanyakan kembali apa yang diucapkan sebelumnya oleh lawan bicara.

Untuk lebih memahami strategi akomodasi komunikasi Mahasiswa Thailand Selatan dalam konteks percakapan dengan lawan bicaranya, maka dapat diuraikan dalam 2 (dua) strategi yang dilakukan, yaitu Pemusatan (Konvergensi) dan Pemisahan (Divergensi). Dalam penggalian data melalui observasi, peneliti tidak menemukan adanya upaya akomodasi berlebihan diantara para informan, dimana overakomodasi cenderung negatif dan menimbulkan stereotip negatif diantara pelaku komunikasi.

\section{Pemusatan (Konvergensi)}

Konvergensi merupakan strategi individu dalam berkomunikasi dengan lawan bicara. Dalam konvergensi, individu akan beradaptasi dengan kecepatan bicara, bahasa, jeda bicara, senyuman, tatapan mata, perilaku verbal, maupun nonverbal (West \& Turner, 2007). Strategi konvergensi yang dilakukan Mahasiswa Thailand Selatan di Kampus UHAMKA adalah dengan cara cara menyesuaikan beberapa perilaku komunikasi baik secara verbal maupun nonverbal. Menurut Muhammad (2005), komunikasi verbal dibedakan menjadi dua bentuk yaitu lisan dan tulisan. Berdasarkan pernyataan tersebut, maka penelitian ini memfokuskan pada komunikasi lisan sesuai dengan konsep akomodasi itu sendiri yang terjadi pada percakapan yang dilakukan oleh pelaku komunikasi.

Mahasiswa Thailand Selatan yang sedang sedang menempuh studi S1 di 
UHAMKA memiliki dorongan yang cukup kuat untuk mempelajari Bahasa Indonesia yang mereka gunakan selama mereka berbaur dan melakukan pembicaraan atau percakapan dengan teman, dosen, dan lingkungan tempat tinggal di Jakarta. Dari kelima informan yang telah diwawancarai, terungkap bahwa bahasa ibu di tempat asal mereka memiliki pengaruh yang cukup kuat dalam kecepatan mereka melakukan pemahaman terhadap berbagai kosa kata dalam Bahasa Indonesia. Informan 1 mengatakan bahwa ia cukup mengalami kesulitan dalam menguasai Bahasa Indonesia dikarenakan dalam percakapan seharihari di Thailand, yang bersangkutan tidak menggunakan Bahasa Melayu yang notabene memiliki kemiripan dengan Bahasa Indonesia, namun menggunakan Bahasa Thailand (karena ayahnya berasal dari Yala - dimana masyarakat di sana menggunakan bahasa pengantar bahasa Thailand), sebagaimana hasil wawancara berikut : “...saya susah sekali, tidak bisa kuat ngerti Bahasa Indonesia, soalnya di Thailand engga pake Bahasa Melayu seperti teman (Thailand Selatan) yang lain. Papa tadinya orang Buda, lalu menjadi muallaf, menikah dengan Mama. Sehari-hari bercakap dengan Bahasa Thailand. Dan Saya sekolah tidak di sekolah Melayu, tapi di sekolah umum, jadi tak pandai bahasa melayu...tapi Saya tetap belajar Bahasa Indonesia selama kuliah di sini....".

Dengan tidak dikuasainya bahasa Indonesia dengan baik, maka Informan 1 mengaku sangat bingung, sedih, dan merasa asing. Namun, dalam berdialog dengan lawan bicara, Mahasiswa Thailand Selatan mempertahankan upaya penguasaan bahasa yang bisa saling dipahami, yaitu Bahasa Indonesia. Upaya tersebut merupakan strategi konvergensi yang terwujud dalam bentuk komunikasi verbal. Hal tersebut sesuai dengan apa yang dikemukakan oleh West dan Turner (2010:220), bahwa strategi konvergensi merupakan strategi ang digunakan oleh komunikator untuk beradaptasi dengan segala bentuk komunikasi verbal dan nonverbal yang dimiliki oleh lawan bicaranya, dalam hal ini adalah bahasa dan kata dalam bentuk lisan.

Tujuan Mahasiswa Thailand Selatan melakukan konvergensi tentunya adalah untuk menciptakan hubungan yang akrab, hangat dan harmonis antarteman kuliah yang didominasi dengan penggunaa Bahasa Indonesia sehingga tercipta komunikasi yang efektif, sehingga dapat dipahami bahwa konvergensi ini merupakan strategi yang mengutamakan komunikasi sebagai proses penciptaan dan berbagi secara bersama terhadap informasi dalam rangka mencapai tujuan saling mengerti diantara para pelaku komunikasi. Hal lain yang bisa didapatkan adalah pengenalan budaya lawan bicara (mahasiswa Indonesia) sehingga dapat menyesuaikan satu sama lain. Dalam penelitian ini terungkap bahwa informan memiliki keragaman dalam hal kebutuhan waktu untuk penyesuaian diri dengan budaya yang ada di sekitar mereka, terutama soal makanan, perilaku masyarakat, bahkan situasi orang-orang di jalanan menjadi faktor keterkejutan mereka. Secara umum, para informan mengungkapkan bahwa meskipun terdapat perbedaan dalam beberapa hal 
yang bersifat kultural, mereka mengatakan ada kemiripan dengan tempat asal mereka, terutama agama mayoritas di Indonesia adalah Islam. Dalam rangka untuk mewujudkan komunikasi efektif dalam hal kesamaan bahasa, maka berbagai upaya dilakukan oleh Mahasiswa Thailand Selatan dalam menguasai Bahasa Indonesia, di antaranya:

1) Mengikuti pendampingan dan pelatihan Bahasa Indonesia. Pada awal memasuki perkuliahan, UHAMKA memfasilitasi pelatihan Bahasa Indonesia oleh Dosen Pendidikan Bahasa dan Sastra Indonesia bagi Mahasiswa Baru dari Thailand Selatan yang dilaksanakan di Rusunawa Kampus UHAMKA Pasar Rebo, Jakarta Timur. Ketika mereka baru tiba di UHAMKA, Rusunawa UHAMKA menjadi tempat tinggal pertama mereka, meskipun kemudian mereka berpencar mencari tempat lain yang mereka anggap lebih kondusif. Namun pelatihan tersebut menurut mereka tidak terlalu signifikan karena berbagai hal, diantaranya : cara penyampaian para fasilitator yang tidak sama sehingga penerimaan dan pemahaman terhadap Bahasa Indonesia pun tidak sama diantara mahasiswa Thailand Selatan. Bagi mahasiswa yang kuliah di kampus Limau, jarak dan waktu tempuh menjadi persoalan karena menjadi menyita waktu dan tenaga untuk perjalanan kampus Limau - Rusunawa Pasar Rebo guna mengikuti pelatihan, sehingga mereka hanya bertahan selama satu bulan.

2) Mengintensifkan percakapan dengan lawan bicara terutama teman kuliah.
Mahasiswa Thailand Selatan tidak melakukan penghindaran, tetap berusaha meleburkan diri dalam interaksi dengan teman-teman kuliah. Dalam melakukan relasi pertemanan, beberapa informan cenderung memilih beberapa teman yang memiliki atensi lebih pada mereka.

3) Mengikuti kursus Bahasa Indonesia di luar kampus UHAMKA. Kursus ini dilakukan oleh Informan 3 dengan cara mengikuti pelatihan Bahasa Indonesia di Pare, Kediri, Jawa Timur selama 1 (satu) bulan pada saat libur semester ganjil 2014/2015.

Tujuan dari konvergensi adalah untuk menciptakan integrasi sosial atau identifikasi satu sama lain, meningkatkan ketertarikan, keterdukungan, kejelasan dan keterlibatan antarpribadi dari pembicara (speaker) dalam pandangan penerima (recipients). Konvergensi dilakukan dalam hal percakapan dan juga perilaku-perilaku nonverbal. Perilaku nonverbal yang ditunjukkan mahasiswa Thailand Selatan dalam menjalani komunikasi antarbudaya dengan mahasiswa asal Indonesia adalah dengan melakukan gerakan-gerakan, gesture, maupun isyarat yang biasa dilakukan oleh teman-teman mereka mahasiswa Indonesia, seperti memberikan senyuman, anggukan tanda persetujuan dan isyarat tangan.

Konvergensi dilakukan oleh Mahasiswa Thailand Selatan dalam upaya menciptakan hubungan yang lebih intim, adanya keinginan untuk dapat dibantu oleh orang lain, terutama dalam persoalan memahami materi perkuliahan. Konvergensi dapat pula dianggap sebagai refleksi atas 
keinginan individu dalam persetujuan sosial (social approval).

\section{Pemisahan (Divergensi)}

Divergensi merupakan strategi akomodasi komunikasi, dimana ketika para pelaku komunikasi menunjukkan masing-masing perbedaan dalam sebuah percakapan. Menurut Giles dan Noels (2016); divergensi mengarahkan pada cara pembicara mengaksentuasi tuturan dan perbedaan-perbedaan nonverbal antarpelaku komunikasi; divergensi didesain untuk menekankan perbedaan (distinctiveness) dari lawan bicara dan biasanya terjadi pada keanggotaan sebuah kelompok.

Dalam interaksi antarbudaya Mahasiswa Thailand Selatan dengan mahasiswa Indonesia dan juga lingkungan secara umum, mereka tetap memperlihatkan diferensiasi secara bahasa, terutama dalam perilaku percakapan yang tetap menunjukkan perbedaan aksen (accent divergence) dalam percakapan dengan mahasiswa Indonesia, dosen, dan orang di sekitar. Hal ini dapat dipahami karena mereka diharuskan berbicara dan memahami Bahasa Indonesia untuk berkomunikasi untuk dapat diterima oleh lingkungan, dan tidak untuk menunjukkan identitas budaya.

Dalam wawancara dengan para informan; terungkap bahwa mereka mengatakan sulit atau belum bisa mengikuti aksen para penutur asli Bahasa Indonesia (mahasiswa Indonesia), apalagi ketika teman-teman Indonesia menggunakan istilah-istilah atau kosakata yang tidak baku (bahasa gaul atau bahasa 'alay'). Hal ini kemudian mendorong mereka untuk tetap mendivergensi diri dengan tetap menggunakan aksen melayu, sebagaimana hasil wawancara dengan Informan 3 dan Informan 4:

“....kami tak pandai mengikuti cara bicara orang Indonesia, kami tak bisa rubah aksen. Kami hanya terbiasa dengan bicara orang Melayu, meski kami juga pake bahasa Thai, tapi tak apalah....yang penting kami paham Bahasa Indonesia saat bicara lah...."

Realitas yang terungkap pada mahasiswa Thailand Selatan tersebut sejalan dengan premis Tajfel dalam Teori Identitas Sosial (Giles \& Noel; 2016) yang mengatakan bahwa akomodasi komunikasi memperlihatkan dimana individu-individu melakukan kategorisasi dunia sosial dalam kelompok-kelompok dan menunjukkan berasal dari mana identitas dan jati diri (yang kemudian disebut identitas sosial), dari kelompok mana mereka berasal. Fenomena yang serupa dengan divergensi ini juga dipahami sebagai 'maintenance', dimana seseorang akan melanjutkan atau mempertahankan gaya bicara sesuai asal usul daripada melakukan konvergensi.

Divergensi yang terlihat dalam percakapan yang dilakukan oleh para informan adalah pada saat mereka berkelompok dengan mahasiswa lain dan dalam kelompok tersebut ada sesama mahasiswa Thailand Selatan yang lain (kakak atau adik kelas), maka mereka tetap saling bicara dalam Bahasa Thailand, meskipun di sekitar mereka adalah teman-teman mahasiswa Indonesia. Meski mereka paham bahwa teman-teman Indonesia tidak mengerti arti percakapan mereka, namun apa yang mereka pilih dalam percakapan antarmereka adalah karena aspek kenyamanan yaitu kecepatan bicara dan 
pemaknaan bahasa yang lebih mudah, serta keterikatan budaya dan negara yang sama.

Divergensi tidak bersifat negatif dan divergensi tidak sama dengan ketidakpedulian, ketika seseorang memutuskan untuk melakukan divergensi, maka mereka memutuskan untuk mendisosialisasikan diri mereka dari komunikator dan percakapan tersebut (West \& Turner, 2010).

Perbedaan aksen merupakan cara menciptakan kenyamanan pada saat berkomunikasi, selain itu juga menunjukkan keunikan budaya yang pada ujungnya akan menciptakan komunikasi yang efektif. Divergensi dilakukan sebagai upaya penyeimbangan untuk memepertahankan identitas budaya masing-masing khususnya dalam hal budaya komunikasi tanpa ada niat untuk menghindari satu sama lain.

Akomodasi bukanlah proses yang terjadi secara satu arah (one-way), namun dalam setiap peristiwa komunikasi, lawan bicara dapat saja melakukan konvergensi maupun divergensi atau mempertahankan perbedaan. Untuk menggambarkan karakteristik atau sifat konvergensi dan divergensi dalam konteks percakapan dengan penggunaan bahasa tertentu, dapat dilihat dalam tabel berikut:

Tabel 2.

Strategi Akomodasi Komunikasi yang dilakukan Mahasiswa Thailand Selatan dalam Interaksi Antarbudaya di Kampus UHAMKA

\begin{tabular}{cccc}
\hline No & $\begin{array}{c}\text { Strategi } \\
\text { Akomodasi }\end{array}$ & \multicolumn{2}{c}{ Implementasi Strategi } \\
\hline 1 & KONVERGENSI & 1. & Dalam percakapan \\
& & sehari-hari dengan \\
& & lingkungan kampus \\
& & menggunakan \\
& & Bahasa Indonesia \\
& & & \\
& & & \\
& &
\end{tabular}

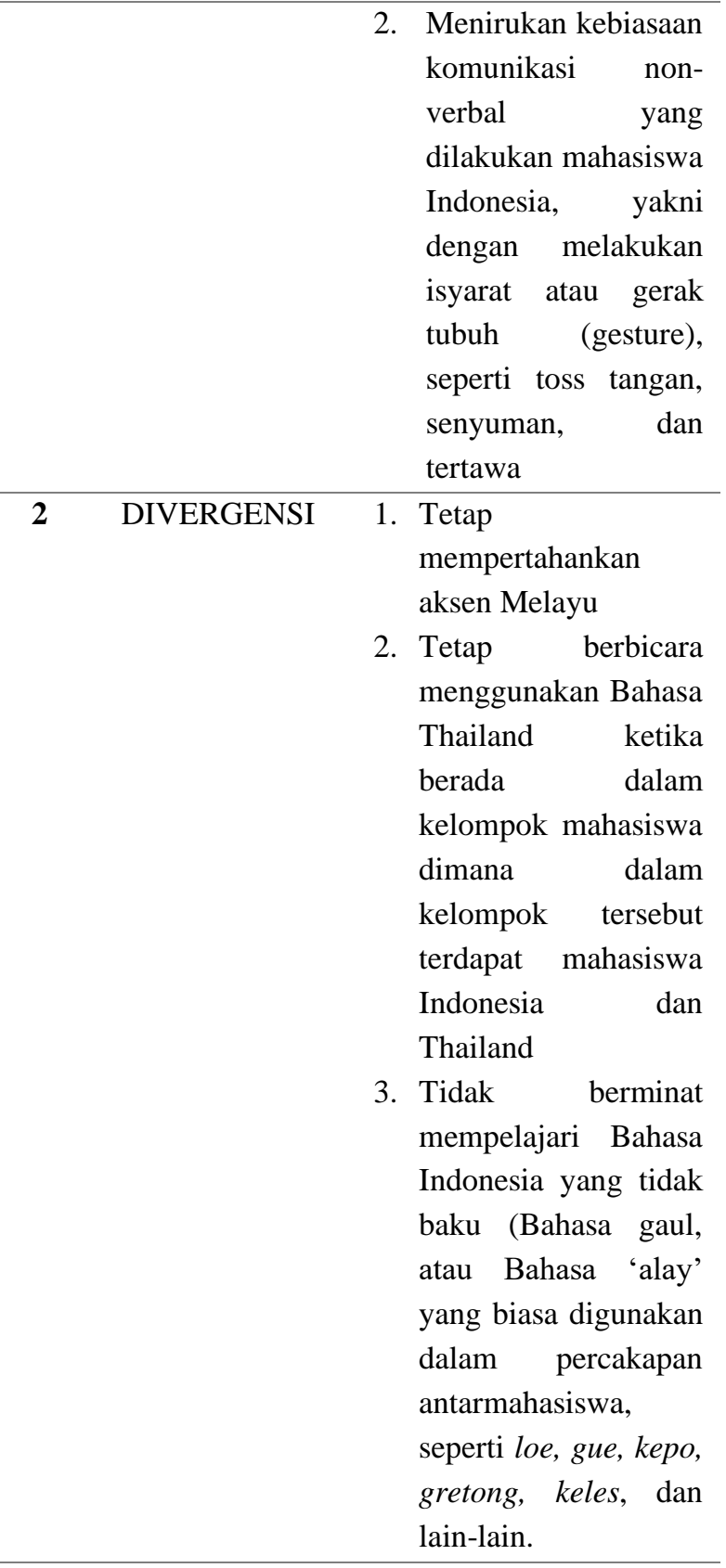

\section{Kesimpulan}

Komunikasi menjadi suatu sarana ataupun perantara untuk membentuk identitas dan juga mengubah mekanisme interaksi antarpelaku komunikasi. Aktivitas komunikasi yang sering dilakukan oleh individu adalah berbicara dengan orang lain dengan menggunakan bahasa yang sama, menunjukkan gerak gerik yang sama, bahkan berbicara dengan kecepatan yang sama, demikian pula sebaliknya ketika kita memberikan respon kepada lawan bicara. Namun dalam kesempatan yang lain, kita 
berbicara dengan lawan bicara yang berasal dari budaya ataupun kelompok yang berbeda dengan kita. Dalam konteks tersebut, maka kita akan menghindari menggunakan bahasa yang tidak dipahami oleh lawan bicara. Setiap individu membawa identitas masing-masing dalam berkomunikasi, namun ketika muncul respon maupun reaksi dari orang lain atau lawan bicara maka secara sadar maupun tidak akan terjadi akomodasi komunikasi.

\section{Acknowledgment}

Penelitian ini tidak dapat berjalan dengan baik tanpa dukungan dari berbagai pihak. Penulis mengucapkan terima kasih kepada Lembaga Penelitian dan Pengembangan Universitas Muhammadiyah Prof. DR. HAMKA (Lemlitbang UHAMKA) yang telah mendukung dan memberikan kesempatan untuk terlibat dalam aktivitas penelitian ini.

\section{References}

Adyapradana, Girindra. 2012, Akomodasi Komunikasi Pemain Game Online dalam Menghadapi Stereotip (Studi Kasus: Stereotip Pemain Indonesia dalam Game Online Battle of Immortal); Jakarta: Departemen Ilmu Komunikasi, Fakultas Ilmu Sosial dan Ilmu Politik, Universitas Indonesia. Tesis tidak diterbitkan.

Alviana, Septa. 2015, Strategi Akomodasi Komunikasi dalam Interaksi Antarbudaya Suku Melayu (Tempatan) dan Suku Jawa di Desa Bukit Gajah Kecamatan Ukui Kabupaten Pelalawan Provinsi Riau. JOM FISIP Volume 2 No. 2, Oktober 2015.

Bungin, Burhan. 2013, Metode Penelitian Kualitatif, Prenada Media, Jakarta,

Creswell, John W. 2010, Research Design, Pendekatan Kualitatif, Kuantitatif, dan Mixed, Pustaka Pelajar, Yogyakarta

Giles, H. \& Noels, K.A. 2007, Communication Accomodation in Intercultural Encounters. Shanghai Foreign Language Education. Shanghai.

Griffin, EM. 2004, A First Look At Communication Theory, McGraw Hill, New York
Herdiansyah, Haris. 2010, Metodologi Penelitian Kualitatif untuk Ilmu-Ilmu Sosial, Penerbit Salemba Humanika, Jakarta

Hendarman. 2013, International Student Mobility : Indonesia, in The International Mobility of Students in Asia and the Pacific, UNESCO, Bangkok

Kim, J.H. \& Standberg, S (Coordinator). 2013, The International Mobility of Students in Asia and the Pacific, UNESCO, Bangkok

Kriyantono, Rahmat. 2008, Teknik Praktis Riset Komunikasi, Kencana Prenada Media Group, Jakarta

Liliweri, Alo, 2007, Dasar-Dasar Komunikasi Antarbudaya, Pustaka Pelajar, Yogyakarta

Littlejohn, Stephen \& Karen A. Foss. 2009, Teori Komunikasi (Theories of Human Communication), Salemba Humanika, Jakarta

Miller, Katherine. 2002, Communication Theories; Perspectives, Process, and Contexts, McGraw Hill, New York.

Moleong, Lexy J. 2007, Metodologi Penelitian Kualitatif, Remaja Rosdakarya, Bandung

Morissan, 2014, Teori Komunikasi; Individu Hingga Massa, Kencana Prenada Media Group, Jakarta

Neuman, W.L. 2011, Social Research Methods : Qualitaitve and Quantitative Approaches, $7^{\text {th }}$ Edition. Allyn \& Bacon, Boston.

Purwasito, Andrik. 2003, Komunikasi Multikultur, Universitas Muhammadiyah Surakarta, Surakarta

Samovar, Larry A; Richard E. Porter, \& Edwin R. Mcdaniel, 2010, Komunikasi Lintas Budaya, Salemba Humanika, Jakarta

Sinlarat. Paitoon. 2013, International Student Moblitiy : Thailand, in The International Mobility of Students in Asia and the Pacific, UNESCO, Bangkok

Tubbs, Stewart L \& Sylvia Moss. 2005, Human Communication, Konteks-Konteks Komunikasi, penerjemah : Deddy Mulyana dan Gembirasari, Remaja Rosdakarya, Bandung

2008,

Human Communication, Prinsip-prinsip Dasar, penerjemah : Deddy Mulyana dan Gembirasari, Remaja Rosdakarya, Bandung

West, Richard \& Lynn Turner. 2010, Introducing Communication Theory: Analysis and Application, McGraw Hill, New York 
Komunika: Jurnal Ilmu Komunikasi

(c) (1)

2020 Oleh authors. Lisensi KOMUNIKA: Jurnal Ilmu Komunikasi, Uhamka, Jakarta. Artikel ini bersifat open access yang didistribusikan di bawah syarat dan ketentuan Creative Commons Attribution (CC-BY) license (http://creativecommons.org/licenses/by/4.0/). 